\title{
Diabetes Complications and Associated Factors in Type 2 Diabetic Patients in Cotonou
}

\author{
François Djrolo1* ${ }^{*}$ Noël M. Paraïso², Oumou Diarra², Michel Makoutode² \\ ${ }^{1}$ Département de Médecine Interne, Faculté des Sciences de la Santé, Unité d’Endocrinologie et Maladies \\ Métaboliques, Cotonou, Bénin \\ ${ }^{2}$ Institut Régional de Santé Publique, Ouidah, Bénin \\ Email: fdjrolofss@yahoo.fr
}

Received 22 August 2014; revised 18 September 2014; accepted 15 October 2014

Academic Editor: Thomas Stief, Institute of Laboratory Medicine and Pathobiochemistry, Germany

Copyright (C) 2014 by authors and Scientific Research Publishing Inc.

This work is licensed under the Creative Commons Attribution International License (CC BY).

http://creativecommons.org/licenses/by/4.0/

(c) (i) Open Access

\begin{abstract}
Long-term complications are the main sources of morbidity and mortality in diabetic patients. Aims: The aims of the study were to determine the rate of long-term complications in type 2 diabetic patients and to identify factors associated to these complications. Patients and method: Successive type 2 diabetic patients attending the diabetic center were submitted to a questionnaire and to clinical examination. Data were completed by consulting their medical reports. Chi square test was used for statistical analysis. Results: In 150 diabetic patients included in the study, the global rate of complications was $\mathbf{7 8 . 0 \%}$. Specific rate for itch complication investigated was $\mathbf{5 7 . 7 \%}$ for peripheral neuropathy, $\mathbf{7 5 . 0} \%$ for erectile dysfunction, $\mathbf{2 0 . 0 \%}$ for nephropathy, $36.6 \%$ for retinopathy, $\mathbf{4 0 \%}$ for macroangiopathy and $\mathbf{8 . 0 \%}$ for foot ulcer. Factors significantly associated with high rate of complications were age above or equal to 50 years $(p=0.001)$, the male gender $(p=0.000)$, high blood pressure $(p=0.0001)$, the absence of familial history of diabetes $(p=0.02)$, the duration of the disease above 5 years $(p=0.001)$ and high HbA1c level $(p=0.001)$. Conclusion: This study revealed that type 2 diabetic patients followed up in the diabetic center in Cotonou showed a high rate of chronic complications which often occurred in a younger age than in developed countries. Numerous socio-demographic and biological factors were significantly associated with the high rate of complications.
\end{abstract}

\section{Keywords}

Diabetes, Complications, Associated Factors

\footnotetext{
${ }^{*}$ Corresponding author.
}

How to cite this paper: Djrolo, F., Paraïso, N.M., Diarra, O. and Makoutode, M. (2014) Diabetes Complications and Associated Factors in Type 2 Diabetic Patients in Cotonou. Journal of Diabetes Mellitus, 4, 311-315. 


\section{Introduction}

Type 2 diabetes mellitus is a growing affection with an epidemic trend that became a public health concern problem worldwide, particularly in developing countries where the estimated progression is higher than in developed countries [1]. In Benin republic, the nationwide prevalence estimated to 1.1\% in 2001 grows up to $2.6 \%$ in 2008 [2] [3] confirming the worldwide epidemic trend reported by King and Rewers in 1993 and Wild in 2004 [4] [5]. The costly aspect of the affection reside in the long term complications which are also sources of over morbidity and mortality in diabetic patients. Knowledge of factors associated with these complications can help to prevent them.

\section{Objective}

The objectives of the present study are to determine the rate of long term complications in the type 2 diabetic patients followed up in the diabetic center in Cotonou and to identify factors associated to these complications.

\section{Patients and Method}

Study population consisted in type 2 diabetic patients from 25 to 64 years old attending the diabetes center. The sampling was constituted by exhaustive sounding of successive diabetic patients received during the study period. With their own consent, patients were submitted to a questionnaire and to a clinical examination. Data were completed by consulting medical reports of patients. Data collection concerned socio-demographic characteristics of patients and long term complications. Complications investigated were:

1) Peripheral neuropathy, based on the presence of subjective man if estations as paresthesia, burning feet, and the abolition of bone reflexes at the clinical examination;

2) Erectile dysfunction;

3) Nephropathy, based on the presence of proteinuria in the absence of other causes of proteinuria;

4) Macroangiopathy, based on the presence of legs arteries disease or ischemic cardiac disease;

5) Retinopathy, based on the presence of specific lesions at the fundoscopy;

6) Data on macroangiopathy were available for only 30 patients and on retinopathy for only 50 patients;

7) Statistical analysis was made using the Chi square test;

8) Research protocol was approved by the Review Board of the Institut Régional de Santé Publique.

\section{Results}

A total of 150 patients were included in this study comprising 93 women (62\%) and 57 men. The mean age of patients was $55 \pm 10$ years.

Out of these 150 patients, 117 presented at least one of the investigated complications meaning a prevalence rate of $78.0 \%$. The specific prevalence rate of each complication is summarized in Table 1.

As it appears in this table, the more prevalent complication observed is neuropathy and three out of four type 2 diabetic men complained of erectile dysfunction.

Study of factors associated with chronic complications in diabetic patients is shown in Table 2 and Table 3.

Table 1. Specific rate of complications.

\begin{tabular}{|c|c|c|c|}
\hline \multirow{2}{*}{ Kind of complication } & \multirow{2}{*}{ Effect if } & \multicolumn{2}{|c|}{ Complication rate } \\
\hline & & $\mathrm{N}$ & Pourcentage \\
\hline Neuropathy & 150 & 88 & $57.7 \%$ \\
\hline Erectile dysfunction & 57 & 43 & $75.0 \%$ \\
\hline Nephropathy & 150 & 30 & $20 \%$ \\
\hline Retinopathy & 50 & 18 & $36.0 \%$ \\
\hline Macroangiopathy & 30 & 12 & $40 \%$ \\
\hline Diabetic foot & 150 & 12 & $8.0 \%$ \\
\hline
\end{tabular}


Table 2. Association with socio-demographic factors.

\begin{tabular}{|c|c|c|c|c|}
\hline \multirow{2}{*}{\multicolumn{2}{|c|}{ Factors }} & \multicolumn{2}{|c|}{ Complications rate } & \multirow{2}{*}{$\mathrm{p}$} \\
\hline & & Effective & Pourcentage & \\
\hline \multirow{2}{*}{ Age (year) } & $30-49(n=44)$ & 23 & $52.3 \%$ & \multirow{2}{*}{0.00} \\
\hline & $\geq 50(n=106)$ & 94 & $88.7 \%$ & \\
\hline \multirow{2}{*}{ Sex } & Men $(n=57)$ & 50 & $91.2 \%$ & \multirow{2}{*}{0.000} \\
\hline & Women $(n=93)$ & 53 & $69.9 \%$ & \\
\hline \multirow[b]{2}{*}{ Provenance } & Rural (n = 16) & 13 & $81.3 \%$ & \multirow[b]{2}{*}{0.73} \\
\hline & $\operatorname{Urban}(n=134)$ & 104 & $77.6 \%$ & \\
\hline \multirow{2}{*}{$\begin{array}{l}\text { Perception of } \\
\text { the diabetes }\end{array}$} & $\operatorname{Bad}(n=47)$ & 42 & $89.4 \%$ & \multirow{2}{*}{0.02} \\
\hline & Good $(n=103)$ & 75 & $72.8 \%$ & \\
\hline \multirow{2}{*}{ Perception of obesity } & Bad (n = 65) & 55 & $84.6 \%$ & \multirow{2}{*}{0.08} \\
\hline & Good $(\mathrm{n}=85)$ & 62 & $72.9 \%$ & \\
\hline
\end{tabular}

(): Number of patients.

Table 3. Association with clinical and biological factors.

\begin{tabular}{|c|c|c|c|c|}
\hline & \multirow{2}{*}{ Factors } & \multicolumn{2}{|c|}{ Complications rate } & \multirow{2}{*}{$\mathrm{p}$} \\
\hline & & Effective & Pourcentage & \\
\hline \multirow{2}{*}{ Obesity } & Obese $(n=75)$ & 60 & $80.0 \%$ & \multirow{2}{*}{0.67} \\
\hline & Normal weight $(\mathrm{n}=25)$ & 19 & $76.0 \%$ & \\
\hline \multirow{2}{*}{ Hypertension } & Yes $(\mathrm{n}=102)$ & 92 & $92.2 \%$ & \multirow{2}{*}{0.000} \\
\hline & No $(\mathrm{n}=48)$ & 25 & $52.1 \%$ & \\
\hline \multirow{2}{*}{$\begin{array}{l}\text { Familial history of } \\
\text { diabetes }\end{array}$} & Yes (72) & 48 & $66.7 \%$ & \multirow{2}{*}{0.001} \\
\hline & No (78) & 69 & $88.5 \%$ & \\
\hline \multirow{2}{*}{ Diabetes duration } & $<5$ years $(72)$ & 47 & $65.3 \%$ & \multirow{2}{*}{0.001} \\
\hline & >5 years $(78)$ & 70 & $89.7 \%$ & \\
\hline \multirow{2}{*}{ Glycated hemoglobin } & $<7 \%(16)$ & 2 & $12.5 \%$ & \multirow{2}{*}{0.00} \\
\hline & $>7 \%(37)$ & 35 & $94.6 \%$ & \\
\hline
\end{tabular}

(): Number of patients.

As shown in Table 2, complication rate was significantly higher in men than in women and type 2 diabetic patients of 50 years or more old showed higher complication rate. Another factor associated with the high complication rate was the patient's own perception of the disease. The high rate of complication was also associated with hypertension, the absence of familial history of diabetes, the duration of diabetes and the high plasma level of glycated haemoglobin (Table 3).

\section{Discussion}

The global complication rate of $78 \%$ revealed by this study is very high since other studies conducted in other countries of the sub-Saharan Africa region have shown lower complication rates of 58\% [6] and 65\% [7]. As the study population has not been randomly selected, this higher complication rate can be explained by the fact that the center where the study has been conducted is a specialized center for diabetes care and can concentrate diabetic patients with particular health problems. 
Mean age of patients of $55 \pm 10$ years observed in our study is similar to what had been reported by Belkhadir et al. [8] and closed to 52 years reported by Touré in Mali [9] but lower than 62 years reported in France [10], showing that in developing countries, diabetes and its complications appear in a younger age than in developed countries.

When specific complications are considered, we can notice that the rate of neuropathy observed in our study is higher than the rate of $45 \%$ reported by Ouerdane et al. [11] but less high than the rate of $80 \%$ observed by Fendi et al. [12] evaluating diabetic neuropathy by the DN4 score. Our rate of neuropathy is conform to results reported by the Diabcare Africa Study with rate of neuropathy ranging from $39.19 \%$ to $63.70 \%$ in different Africa regions [13].

Regarding nephropathy based on proteinuria, the rate of $8.9 \%$ reported by Läcätusu et al. [14] is lower than what we found in our study. In a previous study a lower rate has also been reported in Cotonou [15]. Kabaj et al. reported a rate of $53.85 \%$ of nephropathy in type 2 diabetic patients in Maroco [16].

Investigation of retinopathy revealed a rate of $36.0 \%$ which is less high than the rate of $47.5 \%$ reported by Khadraoui et al. [17] in Tunisia but closed to 36.6\% reported by Tchabi et al. [18] in the north of Benin. In the 150 patients included in our study, only 50 were investigated for retinopathy. This confirms the observation of Rosenberg et al. who reported in their study that only 35\% of studied patients were referred for eye exam showing that screening guidelines for diabetic retinopathy are not often respected by physician [19].

In this study, high global complication rate was associated with several factors in which patients' age and the male gender can be underlined. Another factor significantly associated with the high rate of complications is the perception the patients have of the disease. Those with bad perception of the disease often considered diabetes mellitus as a traditionally induced disease and then spend a long time with traditional healers before attending hospital. This behavior can explain the high rate of complications in relation of a long period of uncontrolled disease.

Factors classically associated with high rate of complications in type2 diabetes such as patients' age, the duration of the disease, the presence of hypertension and high $\mathrm{HbA}_{1} \mathrm{c}$ level have been evidenced in our study. No association was found between complication rate and obesity.

It can be noticed that patients without familial history of diabetes presented significantly higher rate of complications suggesting that those with familial history of diabetes are more prone to better care of their condition than the others.

\section{Conclusion}

This study has shown a high prevalence of long term complications in type 2 diabetic patients attending the diabetic center. It is now well known that the good control of the disease is associated with reduced complications. As the presence of these complications is also associated with the duration of the disease, the challenge must be precocious diagnosis and tight control of diabetes.

\section{References}

[1] IDF Diabetes Atlas (2011) The Global Burden. 5th Edition, 23-43.

[2] Djrolo, F., Amoussou Guenou, K.D., Zannou, D.M., Houinato, D., Ahouandogbo, F. and Houngbe, F. (2003) Prévalence du diabète sucré au Bénin. Louvain Medical, 122, S258-S262.

[3] Djrolo, F., Gbary, A., Houinato, D., Fambo, D. and Djigbenoudé, O. (2011) Prevalence of Diabetes Mellitus and Associated Factors in the General Population in Benin. World Diabetes Congress Abstracts Book, 570, 1774.

[4] King, H. and Rewers, M. (1993) Global Estimate for Prevalence of Diabetes and Impaired Glucose Tolerance. WHO Ad Hoc Diabetes Reporting Group. Diabetes Care, 16, 157-177. http://dx.doi.org/10.2337/diacare.16.1.157

[5] Wild, S., Roglic, G., Green, A., et al. (2004) Global Prevalence of Diabetes: Estimate for the Year 2000 and Projections for 2030. Diabetes Care, 27, 1047-1053. http://dx.doi.org/10.2337/diacare.27.5.1047

[6] Ali, A. (2000) Quelques aspects épidémiologiques du diabète de type 2 au Niger. Louvain Médical, 119, 265.

[7] Charles, D., Gueye, M. and Wade, B. (1997) Diabète du sujet âgé: A propos de 52 observations consécutives. Médecine d'Afrique Noire, 44, 18-23.

[8] Belkhadir, J. and El Alaoui, Z. (1993) Approche épidémiologique du diabète en milieu marocain. Médecine du Maghreb, 37, 35-37.

[9] Touré, A. (1998) Suivi du diabète de type 2: Epidémiologie, traitement et évolution. Thèse de Médecine, Université du 
Mali.

[10] Romon, I., Brindel, P., Fagot-Campagna, A. and Bloch, J. (2003) Analyse de la relation entre l'existence d'une prise en charge pour affection de longue durée et le suivi des recommandations de bonnes pratiques dans le diabète de type 2 . Bulletin Epidémiologique Hebdomadaire, 20, 88-89.

[11] Ouerdane, K., Aouiche, S., Frioui, M., Ait Boudaoud, A., Ragguem, A. and Boudiba, A. (2013) Fréquence de la neuropathie diabétique douloureuse dans une population algéroise de 400 malades. Diabetes \& Metabolism, 39, A30-A31. http://dx.doi.org/10.1016/S1262-3636(13)71739-7

[12] Fendi, O., Khadhraoui, E., Demnati, C., Gaigi, I., Ben Mami, F., Trabelsi, N., Dakhli, S. and Achour, A. (2011) La neuropathie diabétique évaluée par le score DN4. Diabetes \& Metabolism, 37, A81.

[13] Sobngwi, E., Ndour-Mbaye, M., Boateng, K., Ramaiya, K.L., Njenga, E.W., Diop, S.N., Mbanya, J.C. and Ohwovoriole, A.E. (2011) Type 2 Diabetes Control and Complications in Specialized Diabetes Care Centres of Six Sub-Saharian African Countries: The Diabcare Africa Study. Diabetes Research and Clinical Practice, 95, 30-36. http://dx.doi.org/10.1016/j.diabres.2011.10.018

[14] Läcätusu, C.M., Graur, M., Mihai, C., Cijevschi-Prelipcean, C. and Mihai, B.M. (2013) Les lipides, les protéines et le sucre: Connexion entre le bilan lipidique et l'atteinte rénale chez les patients avec diabète sucré de type 1 d'un centre régional. Diabetes \& Metabolism, 39, A98. http://dx.doi.org/10.1016/S1262-3636(13)72039-1

[15] Djrolo, F., Doutetien, C. and Attolou, V. (2001) Etude de la concordance entre la rétinopathie diabétique et la néphropathie dans une population de diabétiques noirs africains à Cotonou, Bénin. Louvain Médical, 120, 305-309.

[16] Kabaj, F., Sbaitri, N. and Mejdoub, G.B. (2013) La microangiopathie: Influence du type de diabète. Diabetes \& Metabolism, 39, A98. http://dx.doi.org/10.1016/S1262-3636(13)72040-8

[17] Khadraoui, E., Fendi, O., Dogrhi, S., Gaigi, I., Falfoul, E. and Gaigi, S. (2011) Rétinopathie diabétique chez les patients diabétiques de type 2. Diabetes \& Metabolism, 37, A88. http://dx.doi.org/10.1016/S1262-3636(11)70857-6

[18] Tchabi, S., Assavedo, C.R., Boni, S., Affo, S. and Doutétien, C. (2011) Aspects épidémiologiques et cliniques de la rétinopathie diabétique au centre hospitalier départemental du Borgou à Parakou, Bénin (à propos de 101 cas). Louvain Médical, 130, 267.

[19] Rosenberg, J.B., Friedman, I.B. and Gurland, E.J. (2011) Compliance with Screening Guidelines for Diabetic Retinopathy in a Large Academic Children's Hospital in the Bronx. Journal of Diabetes and Its Complications, 25, 222-226. http://dx.doi.org/10.1016/j.jdiacomp.2010.11.001 
Scientific Research Publishing (SCIRP) is one of the largest Open Access journal publishers. It is currently publishing more than 200 open access, online, peer-reviewed journals covering a wide range of academic disciplines. SCIRP serves the worldwide academic communities and contributes to the progress and application of science with its publication.

Other selected journals from SCIRP are listed as below. Submit your manuscript to us via either submit@scirp.org or Online Submission Portal.
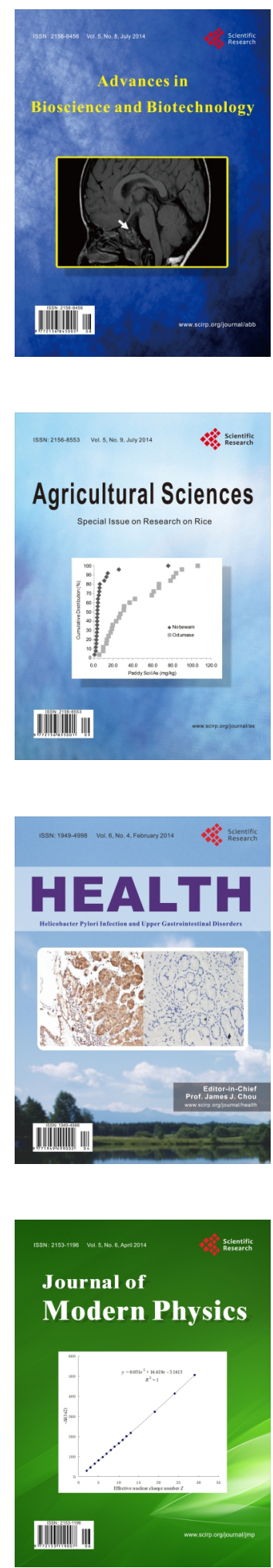
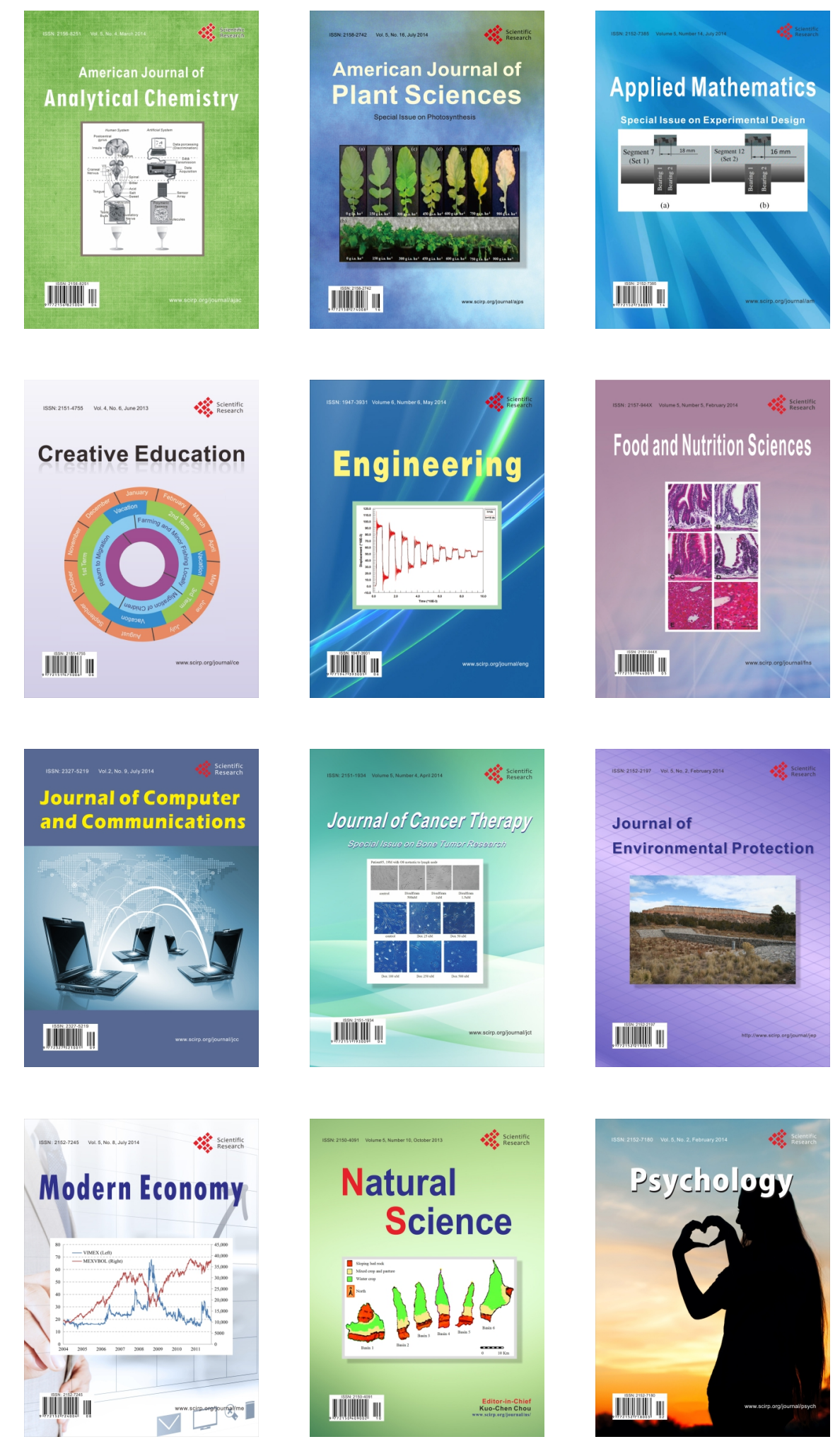